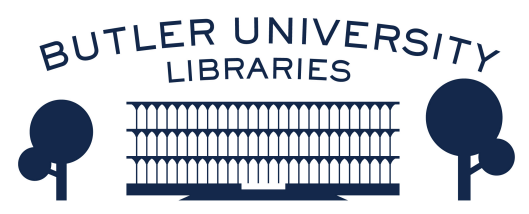

Journal of Hindu-Christian Studies

Volume 22

Article 14

January 2009

\title{
Book Review: "The Bhajan: Christian Devotional Music in Indian Diaspora"
}

George Pati

Follow this and additional works at: https://digitalcommons.butler.edu/jhcs

Part of the Religion Commons

\section{Recommended Citation}

Pati, George (2009) "Book Review: "The Bhajan: Christian Devotional Music in Indian Diaspora"," Journal of Hindu-Christian Studies: Vol. 22, Article 14.

Available at: https://doi.org/10.7825/2164-6279.1441

The Journal of Hindu-Christian Studies is a publication of the Society for Hindu-Christian Studies. The digital version is made available by Digital Commons @ Butler University. For questions about the Journal or the Society, please contact cbauman@butler.edu. For more information about Digital Commons @ Butler University, please contact digitalscholarship@butler.edu. 


\section{The Bhajan: Christian Devotional Music in Indian Diaspora. H. Joy Norman. Cambridgeshire: Melrose Books, 2008, 160 pp.}

IN this book Norman candidly argues the influence of music in Christian worship on the sub-continent of India and in the diaspora where South Asian immigrants have settled. The author investigates how these Indian diaspora Christian communities in England and Trinidad and Tobago, in the process of assimilation have managed to maintain their religious song as distinctly "Indian," while incorporating some musical changes. She discusses historical continuities of the Christian bhajans, a type of devotional singing referring to its antecedents in the bhakti or devotional traditions of Hinduism and its inculturation in Christian worship in India and abroad. Norman states that changes took place among Indian diaspora as they navigated their identity in a new context for which they resorted to Indian Christian lyrics, especially, bhajans which have served as a bridge between the native country and the diaspora context. The bhajans sung in Christian worship in the diaspora acted as a medium to negotiate their religious as well as cultural identities; hence, can be considered as an impetus within the immigrant community. In other words, it carried a world of symbols and meanings; spiritual freedom and a form of establishing and maintaining divine/human relationships.

The author has organized the book into eight chapters. Chapter one, "The Lord's Song in a Foreign Land" sets the context for the study of music and lyrics in Indian Christian Diaspora and ostensibly states religious diversity as an integral part of the Indian socioreligious fabric. Both Indian bhakti traditions as well as Western practices in India highly influenced churches and worship styles. Similar heterogeneity can be observed in its diaspora contexts in England and the Trinidad and Tobago. Norman contends British Asians use of the bhajan includes diversity, besides maintaining their individual cultures. Chapter two, "The Bhajan in Hinduism," asserts the medieval period bhakti movement in Hinduism served as a catalyst to develop music and songs emphasizing devotion of God. Here, she discusses works by various saint poets of medieval bhakti movement which embody love of divine as well as acculturation within the Hindu traditions. Similarly, in the Christian context, bhajans also represent acculturation as they the words and music communicates Christian gospel and love of God and humans.

Chapter three, "Concepts of Sacred Music in Hinduism" investigates the evolution of metrical melody in Hinduism based on the ancient texts and musical tradition emphasizing the significance of ornamentation and harmony. Chapter four, "Missionaries and their Influence on Music in India," highlights the influx of various rituals and musical tradition brought along by these missionaries from their country of origin. As a result, Hindu chanting and European sacred styles of music created a syncretic form of music. Some of the Indian musical elements were identified with European style; for instance, drone, ornamentation, and melodic lines. On the contrary, Western missionaries overlooked improvisation and its genius inherent in Indian music (pp. 75). The author points out that the bhajan served two purposes: a process of indigenization and wider appeal among the masses during Christian worship--as the medieval bhakti poetry.

Chapter five, "Christian Bhakti as Lyrics" argues Christian bhakti poets composed songs and hymns embodying devotion and theology of a personal God comparable to early church lyrics as well as bhakti traditions. The congregation is able to actively participate in the worship experience when because of the simple repetitive musical form of the bhajans as emphasized in chapter six, "Characteristic of the Bhajan used in Christian Worship: Music and Form." While peering through the musical scores of those examples, listening to the bhajans recorded on the compact disc sung during worship service proves beneficial. Chapter seven, "Instruments in Worship," argues that historically voice was the only instrument used for singing God's praise in Hinduism as well as Christian traditions. Indian diaspora uses both Indian and local musical instrument with 
bhajans. Norman concludes the study by posing a pertinent question in chapter eight, "Sing to the Lord a New Song", which remains true for all diaspora communities: what native elements are perpetuated and altered as they are transmitted to the next generation. She infers, in England, secular music has influenced the British Indian Christian worship music and, in Trinidad and Tobago, Afro-Caribbean community music has affected Asian Christian worship. In both instances, they represent a fusion of the Indian and the Western styles.

Clearly, then, the Indian Christian worship in its native context affirms Indian Christianity, which is heterogeneous -- as an amalgam of native Hindu traditions and Western Christian traditions; and in its transplanted context acculturates to the current context, adding to its existing complexity and diversity representing a blending of the East and the West. In this regard, Indian Christian diaspora forges a new wave of Christian worship singing with a purpose to perpetuate and navigate religious and cultural identities. Here, they construct a new Indian Christianity, which is neither totally Indian nor Western--ritualizing on the boundaries--as Indian Hindu diaspora. This study may be beneficial in discussing issues of acculturation and Hindu-Christian encounters within Christian worship in its native and diaspora contexts as it corroborates existing scholarship on medieval Hindu bhakti traditions and Western influences, highlighting the nuances of Indian diaspora Christian worship.

George Pati

Valparaiso University

\section{The Truth, the Way, the Life: Christian Commentary on the Three Holy Mantras of the Srivaisnava Hindus. Francis X. Clooney, S.J. Leuven and Grand Rapids: Peeters Publishers and Wm. B. Eerdmans Publishing Company, 2008, 202 pp.}

THIS book is a delightful and thought provoking Christian commentary on the three holy Mantras of the Srivaisnava Hindu tradition. These Mantras express the core truths of Srivaisnava belief and practice. Francis $X$. Clooney, S.J., carefully exegetes the Mantras in their Srivaisnava context and reflects on the implications of the Mantras for Christian thought and practice. Clooney's perspective and primary audience is Christian; but his commentary is more broadly of interest to those in Srivaisnava studies, Hindu-Christian dialogue, and interreligious/comparative theology.

Clooney begins with a helpful methodological reflection on (interreligious) commentary. Commentary is both academic discipline and spiritual practice. As such, it requires more than hermeneutical skills; it requires submission to the truths of the text. The reader must enter the world of the text as much as possible and read in openness to the meanings and values disclosed by the text. To specify a Christian commentary is therefore somewhat problematic, as it foregrounds the reader, rather than the text. And yet, being aware of the attitudes of the interreligious reader highlights that one can learn from the sacred texts of another tradition.

Clooney depends heavily on Vedanta Desika's (1268-1369) commentary on the Mantras, and organizes the Mantras according to three primary themes in Desika's commentary: the Truth, the Way, and the Life. This grounds the reader in Srivaisnava thought on the Mantras, but also points the Christian reader toward an interreligious bridge; for the Christian reader cannot help but think of the Gospel of John: "I am the way, and the truth, and the life. No one comes to the Father except through me (John 14.6, NRSV)."

Chapter One focuses on the Truth, revealed in the Tiru Mantra: "Aum, obeisance to Narayana." According to Desika, fundamental 